\title{
TAK ZWANI "TUTEJSI" NA POLESIU JAKO ZAGADNIENIE POLITYCZNE W POLSCE W LATACH 1921-1939
}

W raz z zakończeniem negocjacji ryskich i podpisaniem pokoju zamykającego wojnę polsko-bolszewicką W skład II Rzeczypospolitej weszła część ziem niegdysiejszego zaboru rosyjskiego. Znalazła się wśród nich również zachodnia część geograficznego Polesia. Celem prezentowanego tekstu będzie próba charakterystyki problemu konsekwencji przyjęcia przez władze II Rzeczypospolitej, a także część polskiej opinii publicznej założenia o istnieniu tamże zwartej terytorialnie, wielotysięcznej grupy ludności, która nie posiada nowoczesnej - w rzeczywistości rozumianej stereotypowo - świadomości narodowej. Grupa ta była w okresie międzywojennym niekiedy potocznie określana jako tzw. „tutejsi”.

Taka kategoria w opisywanym znaczeniu pojawiła się w polskich danych urzędowych jeszcze w 1919 r., przy czym nie odnosiła się jedynie do Polesia, ale także innych obszarów tzw. "Ziem Zabranych”, a więc tej części zaboru rosyjskiego, która nie została włączona w 1815 r. w skład Królestwa Kongresowego. W niewielkim stopniu została ona wykazana w województwie poleskim $w$ pierwszym spisie powszechnym z 1921 r. (niecate 40 tys.) ${ }^{1}$. Swoje znaczenie $w$ dziejach problemu narodowościowego okresu międzywojennego zawdzięcza temu, że kolejny spis z 1931 r. odnotował na analizowanym tu obszarze wielosettysięczną mase „tutejszych" (ponad 700 tys.), którzy stanowili tym samym około $62 \%$ ludności województwa poleskiego ${ }^{2}$.

Dr hab. Piotr CICHORACKI jest adiunktem w Instytucie Historycznym Uniwersytetu Wrocławskiego. cichoracki@op.pl

1 В.С. Мисциюк, Феномен „тутейших” и национальные процессы в полесском воеводстве (1921-1939 г2.) [w:] Гісторыка-культурная, сz. 1, Брест 2006, s. 207.

2 Drugi powszechny spis ludności z dn. 9 XII 1931 r. Mieszkania i gospodarstwa domowe. Ludność. Stosunki zawodowe. Województwo poleskie, "Statystyka Polska”, seria C, z. 87, Warszawa 1938, s. 20. 
Kwestia znaczenia problemu tzw. „tutejszych” zostanie rozpatrzona w trzech perspektywach. Pierwszą - i niejako wstępną - będzie próba odtworzenia stanowiska, jakie zajmowała w tej sprawie polska nauka i osoby uznawane z ekspertów w dziedzinie mniejszości narodowych. Dla porządku trzeba jednak zaznaczyć, że własne interpretacje zjawiska czynione były również przez badaczy i polityków białoruskich oraz ukraińskich, wysuwających własne roszczenia narodowościowe wobec Polesia. Z takiego punktu widzenia zjawisko „tutejszości” było, rzecz jasna, negowane³. W części drugiej zaprezentowane zostaną opinie funkcjonujące na temat tzw. „tutejszych” w polskiej opinii publicznej. Podstawą analizy będą publikacje skierowane do szerokiego kręgu odbiorców. Część trzecią stanowi prezentacja tych działań podjętych przez władze polskie w okresie międzywojennym, a które były wynikiem ich stosunku do problemu poziomu świadomości narodowej przeważającej części mieszkańców województwa poleskiego. W każdym ze wskazanych trzech wypadków zajmowane stanowisko miało konsekwencje polityczne, czy to w postaci wypracowywanych wniosków, formułowanych postulatów czy, wreszcie, praktycznie prowadzonej polityki narodowościowej.

$\mathrm{Na}$ wstępie rozważań poświęconych teoretycznej analizie problemu "tutejszości” w polskim międzywojennym piśmiennictwie poświęconym problematyce narodowościowej należy podkreślić uwarunkowania, w jakich powstawały analizowane teksty. Najważniejsze wydaje się to, że wszyscy autorzy prac, które można określić zbiorczym, umownym mianem „naukowo-eksperckich”, w mniejszym lub większym stopniu związani byli ze światem politycznym bądź przynajmniej instytucjami państwowymi II RP. W wypadku Leona Wasilewskiego, Konstantego Srokowskiego czy Tadeusza Hołówki sprawa jest oczywista, ponieważ w różnych okresach swojego życia czynnie angażowali się w działalność polityczną. Z kolei przywoływani etnografowie (najważniejsi to Adolf Krysiński, Edward Maliszewski, Józef Obrębski) nie tworzyli swoich prac w politycznej próżni. Wszyscy byli bowiem związani z Instytutem Badań Spraw Narodowościowych (IBSN), będącym przedsięwzięciem znajdującym się - zwłaszcza po przewrocie majowym - pod patronatem władz polskich ${ }^{4}$. Niekiedy udzielali się w przedsięwzięciach wprost firmowanych przez ekipę sanacyjną. Przykładem może być udział Krysińskiego i Obrębskiego w pracach Komisji Naukowych Badań Ziem Wschodnich, funkcjonującej przy Prezydium Rady Ministrów, czy też - jeszcze przed przewrotem majowym - aktywność Maliszewskiego jako rzeczoznawcy w trakcie rokowań ryskich ${ }^{5}$.

W publikacjach IBSN otwarcie deklarowano, że celem prowadzonych badań jest utrwalenie bytu i pełnego rozwoju państwa ${ }^{6}$. Należy więc zgodzić się z twierdzeniem, że jednym z celów prac polskich badaczy było „uzasadnienie polskiej obecności państwowej na tym obszarze"7. Dziś zauważa się jednak, że nawet ci, którzy praktycznie zajmowali swoimi publikacjami stanowisko w sporach narodowościowych (zwłaszcza Krysińskiego uważa się za badacza niekryjącego w publikacjach swojej propolskiej postawy), starali się tak weryfikować dane statystyczne, aby nie powstało wrażenie stronniczości, zazwyczaj

\section{-.....}

3 A. Krysiński, Liczba i rozmieszczenie Ukraińców w Polsce, Warszawa 1929, s. 8; idem, Ludność ukraińska (rusińska) w Polsce w świetle spisu 1931 r., Warszawa 1938, s. 21; B.C. Мисциюк, op. cit., s. 207-208.

4 Z Instytutu Badań Spraw Narodowościowych, "Sprawy Narodowościowe" 1927, nr 1, s. 87.

5 A. Engelking, Polesie Józefa Obrębskiego, [w:] J. Obrębski, Polesie, Warszawa 2007, s. 13; I Zjazd Naukowy poświęcony ziemiom wschodnim w Warszawie 20 i 21 września 1936. Polesie (Sprawozdanie i dyskusje), Warszawa 1938, s. 6, 8, 16; W. Armon, Maliszewski Edward (1875-1928), [w:] Polski Stownik Biograficzny, t. XIX, Wrocław 1974, s. 375.

6 Na temat politycznego kontekstu dziatalności IBSN: W. Olszewski, Tożsamość kulturowa Kresów w humanistycznym nurcie polskiej myśli etnologicznej do roku 1939, Toruń 2007, s. 104, 130, 140; I. Werschler, Z dziejów obozu belwederskiego. Tadeusz Hołówko - życie i działalność, Warszawa 1984, s. 196-201.

7 W. Olszewski, op. cit., s. 224. 
więc obniżali liczbę Polaków ${ }^{8}$ Ich ustalenia uznawane są do dziś za cenne, i traktowane jako podstawa współczesnych szacunków dotyczących struktury narodowościowej II RP9

Świadectwem tego, że nacisk państwowego protektora tychże prac nie był obezwładniający, a badacze formułowali opinię swobodnie i dzielili się z nią otwarcie, były bardzo pesymistyczne konkluzje Józefa Obrębskiego, bez wątpienia autora najbardziej pogłębionych studiów o tematyce poleskiej. Wnioski te dotyczyły negatywnego wpływu administracji na stosunek prawosławnej ludności Polesia do państwa ${ }^{10}$. Wygłaszał je publicznie w obecności przedstawicieli najwyższych władz państwowych, wywołując zresztą ożywioną dyskusję ${ }^{11}$. Przypadek Obrębskiego jest tu interesujący z jeszcze jednego względu. Werbalnie odżegnywał się on od formułowania wniosków natury politycznej. Być może należy traktować to jako próbę samoobrony człowieka nauki przed pozabadawczymi uwikłaniami12. Próbę zresztą o tyle jednak nieudaną, że jego teksty wręcz nasycone są konstatacjami, które trudno określić inaczej aniżeli jako mające polityczny charakter. Trzeba tu nadmienić, że miejsce Polesia w polskich analizach kwestii narodowościowej zmieniało się. Jeszcze w pierwszej połowie lat 20. Wasilewski uspakajająco stwierdzał, że problemy narodowościowe $w$ tym regionie nie są palące, w związku z czym - w przeciwieństwie do województw południowo-wschodnich - nie trzeba spieszyć się z ich rozwiązywaniem ${ }^{13}$. W kolejnej dekadzie obszar ten stał się przedmiotem zróżnicowanych, szeroko zakrojonych badań prowadzonych przez IBSN, ale w sposób oczywisty inspirowanych przez władze $^{14}$. Najwyraźniej uznały one, że diagnozy podobne do sformułowanej niegdyś przez Wasilewskiego zdezaktualizowały się.

W polskich analizach i badaniach problem grup o nie do końca wykrystalizowanej świadomości narodowej był podejmowany niejednokrotnie. I choć Polesie musiało wydawać się szczególnie interesującym polem do podobnych rozważań, to "Poleszucy" nie zawsze służyli autorom analiz do egzemplifikacji15. Sam termin „tutejsi” („miejscowi”) na określenie grupy o wspomnianej cesze zaistniał w polskim piśmiennictwie podejmującym zagadnienia narodowościowe jeszcze przed 1918 r. Jeśli zagadnienie zauważano, nie wiązano jego istnienia z żadnym konkretnym regionem. "Tutejsi mówiący po "prostemu»" byli zapewne traktowani jako charakterystyczne zjawisko dla znacznej części niegdysiejszego Wielkiego Księstwa Litewskiego ${ }^{16}$. Nawet tak ogólnikowe konstatacje nie były jednak wówczas regułą przy opisie etnograficznym tego terytorium. Problem bywał po prostu pomijany ${ }^{17}$. Zmieniło się to na początku lat 20., kiedy Polesie traktuje się już jako wyróżniające pod względem niskiej świadomości narodowej ${ }^{18}$. Zwłaszcza w pierwszych latach niepodległości sięgano po zwroty faktycznie synonimiczne. Czynił tak Maliszewski piszący o mieszkańcach Polesia jako „stanowiących typ przejściowy pomiędzy Białorusinami

\section{- ....}

8 Ibidem, s. 131, 169, s. 233.

W. Michowicz, Problemy mniejszości narodowych, [w:] Polska odrodzona 1918-1939. Państwo-społeczeństwo - kultura, red. J. Tomicki, Warszawa 1988, s. 288; B. Stoczewska, Litwa, Białoruś i Ukraina w myśli politycznej Leona Wasilewskiego, Kraków 2009, s. 234.

10 J. Obrębski, Dzisiejsi ludzie Polesia, [w:] idem, Polesie, Warszawa 2007, s. 294-300.

11 I Zjazd Naukowy..., s. 47-63.

12 Il Ogólnopolski Zjazd Socjologów, „Sprawy Narodowościowe” 1935, nr 5, s. 543; I Zjazd Naukowy..., s. 62.

13 W. Olszewski, op. cit., s. 262.

14 A. Engelking, op. cit., [w:] J. Obrębski, Polesie, Warszawa 2007, s. 13-14 [tamże bibliografia opublikowanych wyników badań]; Sprawozdanie z działalności Instytutu Badań Spraw Narodowościowych za czas od 21 III 1934 r. do 31 III 1935 r., „Sprawy Narodowościowe” 1935, nr 1-2, s. 140-141

15 S. Orsini-Rosenberg, Procesy rozkładowe w grupach etnicznych niezorganizowanych, Warszawa 1933; J. Obrębski, Dzisiejsi ludzie Polesia, [w:] idem, Polesie, Warszawa 2007, s. 283. W. Olszewski, op. cit., s. 124.

16 L. Wasilewski, Kresy Wschodnie. Litwa i Białoruś - Podlasie i Chełmszczyzna - Galicja Wschodnia - Ukraina, Kraków 1917, s. 52.

17 E. Maliszewski, Polskość i Polacy na Litwie i Rusi, Warszawa 1916, s. 23.

18 K. Srokowski, Sprawa narodowościowa na kresach wschodnich, Kraków 1924, s. 9. 
i Małorusinami"19. Stosowanie tego terminu nie uniemożliwiało jednoczesnej konstatacji określonego - niejako obiektywnego - charakteru etnicznego badanej grupy²0. Niekiedy ograniczono znaczenie zjawiska, ograniczając liczbę „tutejszych"21. Sformułowanie budzito także kontrowersje. Otwarcie zanegował jego sensowność Obrębski. Przyznawat, że Polesie to obszar "beznarodowy czy ponadnarodowy"22. Pojęcie „tutejsi” uznał jednak nie tylko za kategorię sztuczną przy określeniu języka czy narodowości, ale wręcz narzuconą - jak należałoby rozumieć przez administrację polską - ludności23. Termin był jednak używany w nauce do końca okresu międzywojennego ${ }^{24}$.

Wszyscy analizowani autorzy byli zgodni, że „tutejszość” to stan przejściowy także w ujęciu czasowym. Uznawano, że nieuniknione będzie dokonanie wyboru narodowościowego przez tak zakwalifikowanych mieszkańców Polesia. Charakterystyczna wydaje się tu opinia Wasilewskiego, który „tutejszość” uznawał za „anomalię skazaną na zanik”25. W latach 20. jako perspektywiczne brane były pod uwage jedynie dwie opcje: białoruska i ukraińska ${ }^{26}$. U progu niepodległości Wasilewski twierdził, że mieszkańcy Polesia ciążyć będą raczej ku świadomości białoruskiej ${ }^{27}$. W latach 20., zapewne także pod wrażeniem rozmachu aktywności Ukraińców w II RP, skłaniano się generalnie ku drugiej opcji28. Największą ostrożność wykazywał piszący w drugiej połowie lat 30. Obrębski. Odżegnywał się od twierdzenia, jakoby na Polesiu istniała „tendencja” do unarodowienia. W jego opinii można było mówić zaledwie o jej "zapowiedzi"29. Nową jakość wniosły te jego wnioski, w których reinterpretował sytuację polityczną zaistniałą na Polesiu w poprzedniej dekadzie. Nie przeceniał on bowiem w kontekście procesów narodowościowych poparcia ludności miejscowej dla konkretnych inicjatyw politycznych. Ani sukces białoruskiej „Hromady" w połowie lat 20., ani rola odgrywana kilka lat później przez ukraiński Sel-Rob nie przesądzały jego zdaniem o akcesie do jednej bądź drugiej opcji narodowościowej. W ujęciu Obrębskiego był to jedynie sposób wyrażenia aspiracji socjalnych i ekonomicznych, nie zaś narodowych. Dopuszczał jednak, że to doświadczenie w przyszłości może odegrać rolę $\mathrm{w}$ procesie identyfikacji narodowej ${ }^{30}$.

Charakterystyczne, że rozpatrujący zagadnienie działacze polityczni - związani historycznie z lewicą i sympatyzujący z obozem piłsudczykowskim - podkreślali pozytywne konsekwencje dostrzeganego przez nich procesu pozyskiwania białoruskiej bądź ukraińskiej świadomości narodowej ${ }^{31}$. Hołówko nie bez egzaltacji pisał o tym, że Polesie i Wołyń staną się „wielką kuźnią”, w której dokona się pożądane nabycie przez miejscową lud-

\section{-.....}

19 E. Maliszewski, Przewodnik po Gubernji Mińskiej. Zarys statystyczno-opisowy, Warszawa 1919, s. 7. Zbliżone stwierdzenie: idem, Przewodnik po Gubernji Grodzieńskiej. Zarys statystyczno-opisowy, Warszawa 1919, s. 6.

20 A. Krysiński, Ludność ukraińska..., s. 24.

21 T. Hołówko, Kwestia narodowościowa w Polsce, Warszawa 1922, s. 36.

22 J. Obrębski, Dzisiejsi ludzie Polesia, [w:] idem, Polesie, Warszawa 2007, s. 277.

23 Idem, Lud bez ojczyzny. Uzupetnienie, [w:] idem, Polesie, Warszawa 2007, s. 273.

24 S. Dworakowski, Rubież polesko-wotyńska, "Sprawy Narodowościowe” 1938, nr 3, s. 231; A. Krysiński, Ludność ukraińska..., s. 24, 25.

25 L. Wasilewski, Stosunki narodowościowe na ziemiach wschodnich Rzeczypospolitej, [w:] idem, Sprawy narodowościowe $w$ teorii i życiu, Warszawa 1929, s. 87.

26 A. Krysiński, Liczba i rozmieszczenie Ukraińców..., s. 8.

27 B. Stoczewska, Litwa, Białoruś i Ukraina w myśli politycznej Leona Wasilewskiego, Kraków 2009, s. 188190; L. Wasilewski, Kresy Wschodnie. Litwa i Białoruś - Podlasie i Chełmszczyzna - Galicja Wschodnia Ukraina, Kraków 1917, s. 57.

28 A. Krysiński, Liczba i rozmieszczenie Ukraińców..., s. 8. Poglądy w tej kwestii zmienił także Wasilewski, B. Stoczewska, op. cit., s. 231; L. Wasilewski, Stosunki narodowościowe..., [w:] idem, Sprawy narodowościowe..., s. 86, 99.

29 J. Obrębski, Dzisiejsi ludzie Polesia, [w:] idem, Polesie, Warszawa 2007, s. 285, 287.

30 Ibidem, s. 302, s. 304.

31 L. Wasilewski, Sprawa Kresów Wschodnich i mniejszości narodowych w Polsce, Warszawa 1925, s. 21. 
ność białoruskiego bądź ukraińskiego oblicza ${ }^{32}$. Podobne obserwacje miewały wyraźnie antyrosyjski wydźwięk. „Tutejszość" traktowano jako jaskrawe zaprzeczenie tezom o kulturowej i językowej rosyjskości Polesia ${ }^{33}$.

Swoistą konsekwencją tezy o perspektywicznej nietrwałości kategorii „tutejszych” były próby rozdzielania ludności Polesia pomiędzy żywioł białoruski i ukraiński. Wydaje się, że - biorąc przynajmniej pod uwagę teksty Wasilewskiego - przed 1918 r. nie sprawiało to problemów ${ }^{34}$. W realiach II RP wątpliwości nie tylko pojawiły się, ale wręcz przesądziły o wnioskach. Niemniej próby podejmowane były nadal, choć ze świadomością, że ścisłe przeprowadzenie takiej linii jest zadaniem trudnym, czy wręcz niemożliwym, właśnie ze względu na niski stopień zaawansowania świadomości narodowej ludności ${ }^{35}$. Konstatowane bywało rozróżnienie pomiędzy względną łatwością określenia granicy językowej, a trudnościami, jakie nastręczała granica narodowościowa ${ }^{36}$. Tłem mogła być „destrukcyjna" w tym wypadku refleksja metodologiczna ${ }^{37}$. Inną determinantą był zazwyczaj negatywny stosunek do wiarygodności wyników spisu powszechnego z 1921 r., które odnosiły się do Polesia ${ }^{38}$. Kolejny spis również zresztą budził zastrzeżenia, choć nie artykułowano ich tak dobitnie ${ }^{39}$. Między innymi w związku z kłopotami statystycznymi zastrzegano więc najczęściej, że dokonywany podział jest bardzo względny. Dla podkreślenia tego stanu rzeczy używano takich umownych określeń jak np. „mgławica” czy „oś krystalizacji”40. Szukano narzędzia uniwersalnego. Widać to zwłaszcza w pracach Krysińskiego, który konsekwentnie stosował metodę rozdzielania deklaratywnych „tutejszych" na podstawie wzajemnej relacji odsetka „świadomych" Białorusinów i Ukraińców występujących w poszczególnych powiatach ${ }^{41}$. Niekiedy jednak otwarcie deklarowana była bezradność wobec "chaosu narodowościowego" i niewiary związanej z tym, że „wobec braku uświadomienia nie tylko narodowego, ale i językowego ludności [...] żaden spis w naszych warunkach nie jest w stanie dostarczyć [satysfakcjonującego] materiału" 42

Wydaje się, że właśnie ze względów politycznych istotny był dla polskich znawców zagadnień narodowościowych i niektórych etnografów kontekst ukraiński. Jeszcze w pierwszej połowie lat 20. bywał on traktowany jako istotniejszy, ze względu na większą - jak oceniano - dynamikę rozprzestrzeniania się na Polesiu świadomości ukraińskiej³. Ton rozważań wyraźnie ewoluował. Według Wasilewskiego ukrainizm, który zaczynał w jego opinii zdobywać pozycje na Polesiu, zwracał się przeciwko rosyjskości będącej pozosta-

$\bullet \cdot \bullet \cdot$

32 T. Hołówko, op. cit., s. 40

33 L. Wasilewski, Rosjanie w Polsce a moskalofilstwo wschodniogalicyjski, [w:] idem, Sprawy narodowościowe $w$ teorii i życiu, Warszawa 1929, s. 110; A. Krysiński, Tendencje rozwojowe ludności Polski pod względem narodowym i wyznaniowym w dobie powojennej (Dokończenie), "Sprawy Narodowościowe” 1931, nr 4-5, s. 438-439.

34 L. Wasilewski, Kresy Wschodnie. Litwa i Białoruś - Podlasie i Chełmszczyzna - Galicja Wschodnia - Ukraina, Kraków 1917, s. 49; idem, Litwa i Białoruś. Przeszłość - teraźniejszość - tendencje rozwojowe, Kraków [1911], s. 81-82

35 A. Krysiński, Liczba i rozmieszczenie Ukraińców..., s. 8. Badacz ten pod koniec lat 30. stwierdzit nawet, że granica taka „jak wiemy nie istnieje”, A. Krysiński, Ludność ukraińska..., Warszawa 1938, s. 22.

36 Idem, Liczba i rozmieszczenie Białorusinów w Polsce, "Sprawy Narodowościowe” 1928, nr 3-4, s. 358.

37 „Nasze - tak często spotykane - dyskusje na temat, czy Poleszucy są Ukraińcami, czy też Białorusinami، i jakimi są właściwie i naprawdę, są po prostu bardziej tylko może zintelektualizowaną formą tej właściwej nam, zorientowanej narodowo kategoryzacji świata społecznego, kategoryzacji naiwnej, ale powszechnej", J. Obrębski, Dzisiejsi ludzie Polesia, [w:] idem, Polesie, Warszawa 2007, s. 301.

38 L. Wasilewski, Stosunki narodowościowe ..., [w:] idem, Sprawy narodowościowe ..., s. 87.

39 B. Zaborski, Liczba i rozmieszczenie mieszkańców Polski wedtug języków i wyznań (uwagi ogólne w świetle spisu 1931 r.), „Sprawy Narodowościowe” 1937, nr 1-2, s. 79.

40 A. Krysiński, Ludność polska a mniejszości w Polsce w świetle spisów ludności 1921 i 1931, Warszawa 1933, s. 44.

41 W. Olszewski, op. cit., s. 137

42 B. Zaborski, op. cit., s. 79.

43 K. Srokowski, Sprawa narodowościowa na kresach wschodnich, Kraków 1924, s. 53. W tym samym czasie proces ten bywał bagatelizowany: L. Wasilewski, Sprawa Kresów Wschodnich..., s. 21. 
łością zaborów. Wasilewski przypuszczał, co prawda, że z czasem może zwrócić się on „przeciw elementom mniej związanym z miejscowym podłożem etnograficznym"44, ale jako te ostatnie zakwalifikował Żydów ${ }^{45}$.

Od przełomu lat 20. i 30. problem ukraiński nabrał zdecydowanie negatywnych konotacji ${ }^{46}$. W analizowanej grupie autorów na czoło wysuwa się tu twórczość Krysińskiego. Dzieje się tak nie tylko ze względu na częstotliwość podejmowania tej kwestii, ale także dostrzegalną ewolucję akcentów. W latach 20., analizując zagadnienie zasięgu żywiołu białoruskiego i ukraińskiego na Polesiu, wyraźnie opowiadał się on za przewagą tego drugie$\mathrm{go}^{47}$. Jeszcze jednak w końcu tejże dekady w swoich konkluzjach dochodził do wniosku, że można zdecydowanie zanegować ukraińskie roszczenia do nadawania Polesiu "charakteru niewątpliwie ukraińskiego" ${ }^{48}$. Zwraca uwagę, że istotną okolicznością towarzyszącą jego tekstom była bieżąca aktywność polityków ukraińskich. Deklarowane przez nich poglądy na wielkość terytorium zamieszkanego i zdominowanego przez żywioł ukraiński wyraźnie budziły opór tego badacza. Stawiał sobie otwarcie za cel określenie "rzeczywistej wielkości tego obszaru" i nie było wątpliwości, że oznacza to jego ograniczenie ${ }^{49}$. W latach 30. wykorzystywał w tym celu wyniki - między innymi językoznawczych - polskich badań zainicjowanych nad Polesiem, czy nawet ustalenia rosyjskiego spisu z 1897 r. ${ }^{50}$ Dochodził do wniosku, że roszczenia ukraińskie prowadzą do statystycznej likwidacji aż 400 tys. „istotnych i potencjalnych” Białorusinów, przede wszystkim zamieszkujących Polesie ${ }^{51}$. Nie przeszkadzało mu to w formułowaniu opinii, że „tutejsi" w przeważającym stopniu powinni zostać zaliczeni do grupy o ukraińskim charakterze etnicznym ${ }^{52}$.

Przed polskimi ekspertami od spraw narodowościowych stanął problem siły miejscowego żywiołu polskiego, co miało ścisły związek z interpretacją zagadnienia siły świadomości narodowej miejscowej ludności. Działo się tak zwłaszcza w świetle spisu z 1921 r., który wykazał aż 24,3\% Polaków, przy jednoczesnym udziale katolików wynoszącym zaledwie 7,8\%53. Dane te $w$ latach 20 . uznano za sprzeczne, w praktyce negując istnienie na Polesiu Polaków wyznania prawosławnego jako grupy istotnej statystycznie. Pogląd taki wyraził Wasilewski, redukując jej udział o ponad $90 \%{ }^{54}$. To, że należy uznać za niewiarygodny gremialny akces do polskości prawosławnych, wyraźnie wyartykułował pod koniec tej dekady Krysiński. Tu istotne, że według niego „przyczyną tego zjawiska był [...] brak jakiegokolwiek poczucia narodowego wśród licznych rzesz ludności kresowej, pomieszanie pojęcia narodowości z pojęciem przynależności państwowej wreszcie, właściwy mało kulturalnym środowiskom oportunizm"55. Dodać wypada, że pogląd wyrażany przez Wasilewskiego i Krysińskiego, negujący istnienie grupy Polaków-prawosławnych, wywołał na łamach „Spraw Narodowościowych" zasadniczą polemikę ${ }^{56}$.

\section{-.....}

44 L. Wasilewski, Jak powstały obecne stosunki narodowościowe w Polsce [1927], [w:] idem, Sprawy narodowościowe..., s. 79-80.

45 Idem, Sprawa Kresów Wschodnich..., s. 21.

46 Idem, Stosunki narodowościowe..., [w:] idem, Sprawy narodowościowe..., s. 87.

47 A. Krysiński, Liczba i rozmieszczenie Białorusinów..., s. 354, 359.

48 Idem, Liczba i rozmieszczenie Ukraińców..., s. 13.

49 Ibidem, s. 4.

50 Idem, Ludność ukraińska (rusińska)..., s. 22, 23.

51 Ibidem, s. 21.

52 Ibidem, s. 24.

53 Skorowidz miejscowości Rzeczpospolitej Polskiej. T. VIII. Województwo poleskie, Warszawa 1924, I"Tablica Wojewódzka"].

54 L. Wasilewski, Stosunki narodowościowe..., [w:] idem, Sprawy narodowościowe..., s. 102.

55 A. Krysiński, Liczba i rozmieszczenie Ukraińców..., s. 22.

56 O. Czarnowski, Polacy prawosławni w Polsce, "Sprawy Narodowościowe” 1929, nr 3, s. 451-478; R. Horoszkiewicz, Przyczynek do sprawy Polaków prawostawnego wyznania, "Sprawy Narodowościowe" 1930, nr 2, s. 229-230. 
Nie oznaczało to jednak, że analiza zawierająca konkluzje dotyczące słabszej w rzeczywistości grupy polskiej, zawsze prowadziła jedynie do wniosku o sile żywiołów białoruskiego i ukraińskiego. To zjawisko „tutejszości” dało Krysińskiemu asumpt do twierdzenia, że jakkolwiek Polesie jest tym regionem Rzeczypospolitej, który zamieszkuje najmniejszy odsetek Polaków, to nie można mówić o tym, że Białorusini i Ukraińcy uzyskali tam przewagę. Argumentowat, że wniosek ten nie może być sformułowany „z powodu dotychczas ani obiektywnie przez etnografię i lingwistyke, ani subiektywnie przez świadomość ludu poleskiego nie stwierdzonej jego narodowej lub językowej przynależności" ${ }^{57}$. Spostrzeżenie to dotyczyło jednak statystycznej strony zagadnienia, nie zawierało natomiast wprost sformułowanej refleksji na temat kierunku, w jakim ewoluować będzie poczucie przynależności narodowościowej „tutejszych”.

Interesujące, że jedynie Obrębski - tak sceptyczny wobec roli miejscowego żywiołu polskiego - przyznawat, że w starciu o narodowościowe oblicze mieszkańców Polesia ważną rolę odgrywa polskość. Inną kwestią jest, że konstatowana przezeń ich fascynacja kulturą polską, której geneza miała brać się z kompleksu niższości, przegrywać miała z poczuciem krzywdy doznawanej w odczuciu Poleszuków ze strony państwa polskiego ${ }^{58}$. Trudno na podobnej płaszczyźnie rozpatrywać natomiast wcześniejsze o ponad dekadę konstatacje Srokowskiego, który po prostu stwierdzat, że właśnie na Polesiu tendencje polonizacyjne są szczególnie dostrzegalne. Rozumiał je bowiem nie jako - ocenianą bardzo sceptycznie - oddolną podatność na kulturę polską, ale jako politykę państwa, zwłaszcza na polu oświaty ${ }^{59}$. Trzeba przy tym podkreślić, że zarówno on, jak i badacze z lat 30. zdecydowanie opowiadali się przeciwko idei „asymilacji politycznej, siłowej”60. Mimo kreślenia różnych scenariuszy dotyczących związania mieszkańców Polesia z tą lub inną wykrystalizowaną już grupą narodowościową, refleksji na temat niskiego poziomu świadomości narodowej towarzyszyły stwierdzenia o odrębności tejże ludności. Teza ta była obecna już w tekstach z lat 20. Srokowski, traktujący w pierwszych latach niepodległości Polski Polesie jako kraj o wyjątkowo słabej świadomości narodowej mieszkańców, przyznawat, że szło to w parze z poczuciem obcości wobec ludzi z zewnątrz, zwłaszcza Polaków61. Hołówko pod koniec dekady pisał o tożsamości „odrębnej acz nienarodowej”62. Obrębski z perspektywy późniejszej, ale przede wszystkim uwarunkowanej własnymi pogłębionymi badaniami terenowymi, problem określit w ten sposób, że na Polesiu funkcjonuje „odrębna grupa etniczna"63. Pod koniec lat 30. na łamach periodyku wydawanego przez IBSN pojawity się wyraźne sugestie, że owa odrębność to efekt - jak należałoby rozumieć pozytywnego wpływu kultury i języka polskiego. To ona, uformowana na fundamencie „tutejszości", miała determinować socjalny, nie zaś narodowy charakter konfliktów społecznych ${ }^{64}$.

Problematyka „tutejszych” znalazła odbicie w nienaukowym piśmiennictwie poświęconym Polesiu. Uwadze polskich obserwatorów nie mogło to zjawisko umknąć, ponieważ stanowiło ono bardzo często istotny element stereotypowego odbioru tego specyficznego regionu. Traktowanie tej kwestii przeszło zauważalną ewolucję, a umowną - i bardzo względną - cezurą wydaje się przełom dekad. W latach 20. opinie publicystyczne,

\section{$\cdots \cdot \cdots$}

57 A. Krysiński, Ludność polska a mniejszości..., s. 19

58 J. Obrębski, Lud bez ojczyzny. Uzupetnienie, [w:] idem, Polesie, Warszawa 2007, s. 275; J. Obrębski, Dzisiejsi ludzie Polesia, [w:] idem, Polesie, Warszawa 2007, s. 286, 288.

59 K. Srokowski, op. cit., s. 51, 53.

60 Określenie zastosowane w stosunku do postawy Krysińskiego w: W. Olszewski, op. cit., s. 170.

61 K. Srokowski, op. cit., s. 9.

62 Cytat za: W. Olszewski, op. cit., s. 237-238

63 J. Obrębski, Lud bez ojczyzny. Uzupełnienie, [w:] idem, Polesie, Warszawa 2007, s. 260; idem, Dzisiejsi ludzie Polesia, [w:] idem, Polesie, Warszawa 2007, s. 277.

64 S. Dworakowski, op. cit., s. 228, 331. 
czy też te formułowane w wydawnictwach popularyzatorskich, poniekąd pokrywały się z późniejszymi ustaleniami polskiej etnografii. Wyrażano bowiem pogląd, że Polesie pod względem etnograficznym jest właściwie terytorium samoistnym i „przejściowym”. Nie negowano jednak, że równocześnie powiązanym z żywiołem białoruskim i ukraińskim ${ }^{65}$. Niekiedy w sposób dosyć jednoznaczny ograniczano w latach 20. terytorialny zasięg "tutejszości", konstatując na terenie województwa poleskiego istnienie znaczących grup biatoruskiej i ukraińskiej66.

Wtedy też pojawiały się sugestie, że zjawisko „tutejszości” jest stosunkowo nowe. Wariantem sposobu deprecjonowania okresu rządów carskich była teza o ich odpowiedzialności właśnie za obecny kształt „tutejszości”. Stworzenie przez władze rosyjskie takiego stanu rzeczy miało być wynikiem zainicjowania procesu, w efekcie którego mieszkaniec Polesia „stracił poczucie przynależności do narodowości polskiej - a nie poczuł się z całą pewnością Rosjaninem czy Białorusinem"67. W innym ówczesnym ujęciu przyznawano, że stan obecny różnit się od tego sprzed wybuchu I wojny światowej. Ten bowiem konflikt dał okazję ludności Polesia do zetknięcia się i "długotrwałego obcowania” z wielotysięcznymi i różnymi armiami. Należałoby więc rozumieć, że obecność najpierw masy wojsk rosyjskich, a później - na części tego terytorium - armii ukraińskiej, spowodowała, iż powstał "pod tym względem znaczny wyłom"68. Negatywna ocena zjawiska nie była jednak normą. Już w latach 20. popularyzowany był pogląd zbliżony do wymowy tez Hotówki czy Wasilewskiego. Uznawano więc, że kłopot z określeniem własnej narodowości przez Poleszuków jest antyrosyjski w wymowie, a więc korzystny dla polskich interesów.

W odniesieniu do kolejnej dekady można uznać, że zazwyczaj w praktyce afirmowano „tutejszość" jako akceptowalne podłoże dla pożądanego procesu polonizacji. Przejściowość etniczna Polesia miała ułatwiać ten proces ${ }^{69}$. Próbowano więc nadawać „tutejszości" znamiona polskie. I tak, na przykład, rozważano skalę wpływu języka polskiego na mowę Poleszuka. Prowadzone szacunki interpretowano jako optymistyczne ${ }^{70}$. Eksponowano znaczenie służby wojskowej. W trakcie jej odbywania Poleszuk dzięki własnej „tutejszości" miał wyjątkowo łatwo, na tle innych przedstawicieli mniejszości narodowych, przepajać się duchem polskim¹. Analogiczne wnioski formułowano, ustosunkowując się do rozwoju oświaty. Za egzemplifikację mogło posłużyć stanowisko starszego pokolenia poleskich chłopów, którzy mieli ze względów utylitarnych deklarować sceptycyzm wobec idei nauki dzieci w języku "miejscowym"72. W latach 30. próbowano wygradzać "tutejszość" od wpływów Wschodu, stawiając tezę o ich - nigdy nieprzełamanej - obcości na Polesiu ${ }^{73}$. Odnotowywano silną identyfikację z prawosławiem przy jednoczesnym odrzucaniu rosyjskości ${ }^{74}$. Podobne w przekazie opinie były formułowane w sposób przesądzający ${ }^{75}$.

Niejako w pośrednim związku z faktem istnienia grupy „tutejszych" doszukiwano się pozostałości pamięci o przynależności do państwa i kultury polskiej ${ }^{76}$. Wydaje się, że w la-

65 W. Mondalski, Polesie, Brześć 1927, s. 201.

66 W. Bieńkiewicz, Niektóre wiadomości o województwie poleskim, [w:] Rocznik Poleski 1927, Brześć 1926, s. 35.

67 R. Horoszkiewicz, Notatki historyczne o niektórych miejscowościach powiatu pińskiego, Pińsk 1928, s. 4.

68 R. Skirmunt, Rys odrębności Polesia, [w:] Polesie llustrowane, Brześć 1923, s. 31.

69 S. Żejmis, Na Polesiu puls bije mocniej... II. "Masuren land-mein Vaterland”, "Bunt Młodych", 1934, nr 14; idem, Na Polesiu puls bije mocniej ... III. Pan wojewoda miesi ciasto, „Bunt Młodych”, 1934, nr 16.

70 M. Marczak, Przewodnik po Polesiu, Brześć 1935, s. 23.

71 F.A. Ossendowski, Polesie, Warszawa 2007, s. 242-243.

72 S. Tołpa, Śladami tosia. Z wędrówek po Polesiu, Lwów 1935, s. 123.

73 F.A. Ossendowski, op. cit., s. 37.

74 S. Żejmis, Na Polesiu puls bije mocniej ... II. "Masuren land-mein Vaterland”, "Bunt Młodych", 1934, nr 14

75 F.A. Ossendowski, op. cit., s. 24.

76 H. Uziembło, Błoto ... bajeczne, Kraków 1934, s. 19. 
tach 20. opinie na ten temat formułowane bywały ostrożniej aniżeli w kolejnej dekadzie ${ }^{77}$. Jako jedno z świadectw traktowano funkcjonujące na wsi wspomnienia odnoszące się do wieku XIX, kiedy chłop szukać miał wsparcia u Polaka-ziemianina w oporze przeciwko codziennym ciężarom carskich rządów ${ }^{78}$. Zaznaczyć jednak wypada, że podobne idealistyczne ujęcie nie było powszechne. Niejednokrotnie przyznano bowiem również, że na przykład powstanie styczniowe wywołało obojętne bądź wrogie stanowisko miejscowego chłopstwa $^{79}$. Zakorzenione przywiązanie do polskości dostrzegano w najdrobniejszych elementach ludowej obyczajowości. W tym właśnie kontekście prezentowana była specyficzna grupa ludności wiejskiej, czyli tzw. szlachta zagrodowa. Intensywniej zainteresowano się nią w drugiej połowie lat 30., choć również wcześniej uznawano jej istnienie jako potwierdzenie wpływów polskości wśród rdzennej ludności Polesia ${ }^{80}$. W latach 30. wskazywano na pewien elitaryzm tej grupy w społecznym krajobrazie prawosławnej wsi ${ }^{81}$. Także $w$ tekstach popularyzatorskich zadawano sobie pytanie o narodową przyszłość grupy "tutejszych". W latach 20. opinie na temat finału tej walki wypowiadano ostrożnie, nie przesądzając finału ${ }^{82}$. W latach 30. jasno deklarowano, że formułowanie tez o związkach żywiołu "tutejszego" z nacją ukraińską czy białoruską to nieuzasadnione „uroszczenia". Koronnym dowodem miał zaś być wynik spisu w $1931 \mathrm{r} .{ }^{83} \mathrm{~W}$ drugim dziesięcioleciu istnienia niepodległej Polski także publicyści bardziej obawiali się w odniesieniu do Polesia ukrainizacji aniżeli białorutenizacji84.

Zarówno badania naukowe, jak i piśmiennictwo niemające podobnego charakteru istniały niejako obok praktycznej działalności władz polskich. W poczynaniach administracji dostrzec można wyraźną ewolucję w odniesieniu do problemu narodowościowego charakteru regionu. Dotyczyło to zwłaszcza poczynań na poziomie średniego szczebla, a więc urzędu wojewódzkiego w Brześciu. Problem, jaki uznawano za konieczny do rozstrzygnięcia w istotnym tutaj kontekście, sprowadzał się do odpowiedzi na pytanie o to, jaki rodzaj asymilacji „tutejszych” jest pożądany z punktu widzenia interesów państwa polskiego.

Jeszcze w pierwszej połowie lat 20. sformułowane zostało przez ówczesnego wojewodę Stanisława Downarowicza założenie, iż na Polesiu grupa nieposiadająca świadomości narodowej dominuje w obrębie mieszkańców wyznających prawosławie. Uznał jednak, że stan ten nie będzie trwały, kwestią czasu jest bowiem nasilenie naporu białoruskiego i ukraińskiego. W przeciwieństwie jednak do takich działaczy jak Hołówko czy Wasilewski - z którymi nb. Downarowicz miał wiele wspólnego, biorąc pod uwage polityczną przeszłość całej trójki - opowiedział się zdecydowanie przeciwko wsparciu, a nawet akceptacji tych trendów. W jego ujęciu stan powyższy powinien przynieść implikacje w postaci realizacji w województwie poleskim odrębnego programu politycznego opartego w praktyce na zasadzie polonizacji. Tak należałoby rozumieć tezę o konieczności „wbicia polskiego klina między czynniki białoruski od północy i ukraiński od południa". Downarowicz przestrzegał, że „byłoby karygodnym brakiem przewidywania i zaniedbania z naszej strony,

79 F. Guściora, Powstanie styczniowe na Polesiu, Brześć 1937, s. 32; Polesia czar, Pińsk 1936, s. 42; M. Marczak, op. cit., s. 34.

80 R. Horoszkiewicz, Powiat stoliński (notatki historyczne), Brześć 1930.

81 H. Uziembło, op. cit., s. 27-28.

82 W. Mondalski, op. cit., s. 232.

83 M. Marczak, op. cit., s. 23; S. Żejmis, Na Polesiu puls bije mocniej... II. "Masuren land - mein Vaterland", "Bunt Młodych", 1934, nr 14

84 "J. M. [J. Mackiewicz], "Konsolidacja” w zwierciadle bagiennym, "Stowo” 1938, nr 15, [w:] J. Mackiewicz, Okna zatkane szmatami, Londyn 2000, s. 261.
} 
a wysoce dla państwa polskiego niebezpiecznym, gdyby czynniki białoruski i ukraiński zdołały podać sobie ręce nad Prypecią"85.

Koncepcje Downarowicza będące w zasadzie pierwszym o charakterze urzędowym, kompleksowym programem polonizacji, nie zostały wdrożone w okresie jego urzędowania, które w dramatycznych okolicznościach dobiegło końca jesienią 1924 r. Stało się tak ze względu na ogólną sytuację w województwach wschodnich, gdzie priorytetem była odbudowa ze zniszczeń wojennych i unormowanie kwestii bezpieczeństwa, zagrożonego zwłaszcza przez komunistyczną akcję wywrotową inspirowaną zza wschodniej granicy. Można natomiast zgodzić się ze współcześnie formułowanym poglądem, że Downarowicz nakreślit strategiczne cele, realizowane przez władze polskie w kolejnej dekadzie ${ }^{86}$.

Po zamachu majowym i zmianach w administracji dokonanych w 1926 r. w dużym stopniu zanegowano istnienie „tutejszych”, uznając, że zasadniczą większość mieszkańców Polesia zamieszkują Białorusini i Ukraińcy. W związku z tym, aby osiągnąć postęp w tzw. "asymilacji państwowej” mniejszości narodowych, należy udzielić tym grupom narodowym koncesji w życiu społecznym i kulturalnym. Pierwsze lata po zamachu majowym wiążą się na Polesiu z nazwiskiem Jana Krahelskiego, sprawującego urząd wojewody w okresie 1926-1932. Czas ten, mimo wielu niejednoznaczności w praktycznych poczynaniach tego urzędnika, należy uznać za najbardziej liberalny w kwestii polityki narodowościowej. Zapewne w dużym stopniu było to efektem jego własnej interpretacji problemu świadomości narodowej przytłaczającej większości prawosławnych mieszkańców poleskiej wsi.

Punkt wyjścia był w wypadku Krahelskiego zbliżony do wyartykułowanego w koncepcji Downarowicza. Uznał więc, że wzmiankowana grupa ludności jest słabo uświadomiona pod względem narodowościowym i że z czasem będzie poddawana coraz silniejszej, oddolnej białorutenizacji i ukrainizacji. Wyciągnął jednak diametralnie odmienne wnioski. W ocenie Krahelskiego należało się z tym procesem pogodzić, nie zaniedbując jednak pracy na rzecz asymilacji państwowej ludności i uczynienia z niej grupy lojalnych obywateli państwa ${ }^{87}$. Oznaczało to w wypadku Krahelskiego zdecydowane odrzucenie hasła polonizacjis8. W takim też duchu instruował podległy sobie aparat. Publicznie atakował „polski nacjonalizm kresowy”, którego zwolennicy "ulegają naiwnemu złudzeniu, jakoby pięść i brutalny ucisk mogły być [...] narzędziem skutecznym na zlikwidowanie tzw. zagadnienia mniejszości", a także deklarował jako stan pożądany brak „jakiegokolwiek ucisku"89.

Krahelski przy końcu swego urzędowania zdobył się na radykalny gest w postaci otwartego, choć niepublicznego, zanegowania najważniejszego z wyników spisu powszechnego z 1931 r., a więc stwierdzenia istnienia wielosettysięcznej grupy "tutejszych". W opracowaniu przeznaczonym dla ministra spraw wewnętrznych stwierdził, że występująca w spisie "grupa beznarodowościowa «miejscowa» została całkowicie sztucznie stworzona kosztem grup ukraińskiej i białoruskiej”. Uznał to za efekt „nieodpowiedzialnej ingerencji ludzi nie umiejących ocenić, jaką szkodę wyrządza nam brak istotnych danych, odzwierciedlających stosunki narodowościowe na ziemiach wschodnich"90.

\section{-.....}

85 Referat wojewody poleskiego dla Wydziału Narodowościowego MSW z 28 || 1923, [W:] Polesie w polityce rządów II Rzeczypospolitej, red. W. Śleszyński, Kraków 2009, s. 23-24.

86 П.А. Абламскі, Планы інтэграціполескага ваяводства зэтнічнай Польшчай, „Моладзь Берасцейшчыны” (Брест) 2009, s. 91-93.

87 Pismo wojewody poleskiego do starostów z 22 VIII 1930, [w:] Polesie w polityce..., s. 45.

88 А.І. Борка, Заканадаўыя асновы дзейнасці адміністрацыйных улад першай інстанцыі на терыторыі Заходняй Беларусі (1921-1939 г2.), „Веснік ГрДу” 2007, seria 1, nr 1, s. 18.

89 Streszczenie przemówienia wojewody poleskiego na zjeździe starostów 20 । 1930, [w:] Polesie w polityce..., s. 38

90 Państwowe Archiwum Obwodu Brzeskiego (dalej PAOB), fond (dalej f.) 1, opis (dalej o.) 9, dieło (dalej d.) 2253, k. 6-7, Referat wojewody poleskiego dla ministra spraw wewnętrznych [1932]. 
W wymiarze praktycznym taka postawa oznaczała zgodę na powiększenie liczby państwowych szkół powszechnych z językiem wykładowym białoruskim i ukraińskim lub utrakwistycznych. Stworzono również kursy językowe dla nauczycieli. Trudno jednak nie zaznaczyć, że w wartościach bezwzględnych była to liczba niewielka (kilkanaście szkół), oraz że zostały one $w$ dużym stopniu zlikwidowane jeszcze w końcu lat 20. ${ }^{91}$ Administracja kierowana przez Krahelskiego zasadniczo tolerowała również rozwój życia kulturalnego białoruskiego (Towarzystwo Szkoły Białoruskiej) i ukraińskiego („Proświta”), o ile nie pojawiły się podejrzenia o działalność komunistycznąą2. Krahelski do końca deklarował się jako zwolennik tezy, że jedynie tolerancja dla ruchu białoruskiego i współpraca z lojalnymi organizacjami ukraińskimi przyniesie na Polesiu pożądane z punktu widzenia państwa efekty. To, że wzmocnienie żywiołu polskiego uznawał za możliwe głównie drogą migracji wewnętrznej, było kolejnym potwierdzeniem, że w jego ocenie problem „tutejszości” był co najmniej przeceniany ${ }^{93}$.

Radykalna zmiana w ujmowaniu przez administracje problemu grupy "tutejszych" datuje się od początku lat 30. Nie tylko powrócono do tezy, że powinni oni zostać poddani polonizacji, ale uznano, że są wręcz na nią szczególnie podatni. Symbolem tego zwrotu, a także autorem jego uzasadnienia, był następca Krahelskiego - Wacław Kostek-Biernacki, który do końca lat 30. stał na stanowisku, że „tutejszość” powinna być traktowana jako jednoznaczna z - choćby potencjalną - polskością ${ }^{94}$. Próby zanegowania podobnego poglądu np. poprzez kwalifikowanie „tutejszych” jako Białorusinów uważał za działalność antypaństwową ${ }^{95}$. Sukces, jakim z punktu widzenia władz była - pozbawiona oporu - likwidacja zorganizowanych przejawów narodowej aktywności białoruskiej i ukraińskiej zinterpretowano jako koronny dowód potwierdzający przyjęte założenie ${ }^{96}$.

Na plan pierwszy zarówno w sferze założeń jak i praktyki Kostek-Biernacki wysuwał kwestie języka. Był to powód, dla którego uznawał on roszczenia białoruskie, ukraińskie czy rosyjskie w stosunku do ludności prawosławnej za nieuzasadnione. Deklarował, że język, jakim posługują się „tutejsi”, jest odrębnym językiem wobec wymienionych wyżej. Jednocześnie w jego ocenie był najbardziej zbliżony do polskiego. Pogląd ten stał się wśród administracji poleskiej aksjomatem, z czasem takie stanowisko zajęły władze centralne ${ }^{97}$. Charakterystyczne dla polonizacyjnego programu Kostek-Biernackiego jest to, że on sam deprecjonował znaczenie mowy "tutejszych", określając ją mianem "gwary"98.

Możliwe rozszerzenie sfery kontaktów Poleszuków z językiem polskim nie oznaczało jednak, że położony był nacisk na zwalczanie ich „macierzystej mowy”. Po kilku latach pobytu na urzędzie wojewody Kostek-Biernacki uznawał, że „Polesie powinno być polskie

91 А.М., Вабішчэвіч, Асвета ў Заходняй Беларусі (1921-1939 г2.), Брэст 2004, S. 24; А.М. Загідулін, Дзржаўная палітіка Польшчы ў галіне беларускай адукацыі (1921-1939 г2.), „Веснік ГрдУ” 2005, ser. 1, nr 2, s. 16 .

92 Referat „Rozwój białoruskiego ruchu narodowościowego na Polesiu” [1933 r.], [w:] Polesie w polityce..., s. 119-124; Referat Wydziału Bezpieczeństwa Urzędu Wojewódzkiego Poleskiego na temat ruchu ukraińskiego na Polesiu z 29 | 1934, [w:] ibidem, s. 141-146.

93 PAOB, f. 1, o. 9, d. 2253, k. 11-21, Referat wojewody poleskiego dla ministra spraw wewnętrznych [1932].

94 А.М. Вабішчевіч, Планы польскіх ўлад па нацыянальнакултурнайасіміла ацыі насельніцтва палескага ваяводствага (1921-1939 г2), „Веснік МДПу” 2008, nr 1, s. 46.

95 Archiwum Akt Nowych (dalej AAN), Ministerstwo Spraw Wewnętrznych, sygn. 1236, k. 104-106, Pismo wojewody poleskiego do ministra spraw wewnętrznych z 7 X 1937 r.; ibidem, k. 125, 126, Pismo wojewody poleskiego do MSW z 30 XII $1937 \mathrm{r}$

96 Polski stan posiadania na Polesiu [1939], [w:] Polesie w polityce..., s. 10

97 PAOB, f. 1, o. 10, d. 2570, k. 11, Pismo kuratora Okręgu Szkolnego Brzeskiego do Ministerstwa Wyznań Religijnych i Oświecenia Publicznego z 1 II 1935; PAOB, f. 1, o. 10, d. 2899 k. 130, 131, Pismo szefa Departamentu Politycznego MSW do Głównego Urzędu Statystycznego z 19 | 1938; W. Paruch, Myśl polityczna obozu pitsudczykowskiego 1926-1939, Lublin 2005, s. 414

98 P. Cichoracki, Droga ku anatemie. Wacław Kostek-Biernacki (1884-1957), Warszawa 2009, s. 263. 
nie patrząc na miejscowe narzecze i wyznanie ogromnej większości mieszkańców"99. Deklarowat, że nie jest konieczne, aby odbierać mieszkańcom Polesia ich "Muttersprache", jak nie bez lekceważenia określał również język, jakim posługiwała się zdecydowana większość miejscowej ludności. Wyrażał uspokajającą opinię, że „trzyma się setkami lat [...] i jest mało wartościowym czynnikiem politycznym"100.

Poniekąd znalazło to odbicie w polityce szkolnej lat 30. Nikła liczba placówek mniejszościowych spowodowała, że jedynym problemem z punktu widzenia władz była nauka religii, prawnie gwarantowana w języku mniejszości. Konkluzja dotycząca odrębności języka „tutejszego" od białoruskiego, ukraińskiego, a zwłaszcza rosyjskiego, w którym zajęcia te prowadzone były najczęściej przez prawosławnych duchownych, dała asumpt do stosowania nacisków w celu ich eliminacji z nauczania tego przedmiotu. W efekcie w ciągu kilku lat zostały one wyeliminowane na rzecz "gwary" i języka polskiego. Administracja zdawała sobie jednak sprawę z tego, że skoro ta pierwsza nie ma skodyfikowanych zasad, kwestią czasu powinna być dominacja języka polskiego ${ }^{101}$.

Odwołując się do danych spisowych i charakteryzując język "tutejszy”, usprawiedliwiono konieczność prowadzenia przez duchownych prawosławnych akt stanu cywilnego po polsku. Wiosną 1933 r. wydano zakaz przyjmowania metryk urodzeń, ślubów i śmierci w innym języku przez państwowe urzędy administracji ogólnej i samorządowe ${ }^{102}$. Miejscowe władze cerkiewne wydały w reakcji na decyzję administracji okólnik o konieczności prowadzenia tej dokumentacji w dwóch językach: polskim i używanym przez parafian. Ta - wydawałoby się kompromisowa - decyzja podjęta w biskupstwie pińskim wywołała jednak wrogą reakcję. Nakazano anulowanie tej dyrektywy w duchu przyznania monopolu językowi polskiemu103.

Uznanie „tutejszości” za grupę obcą trzem wskazanym wyżej narodowościom wschodniosłowiańskim generowało w stosunku do nich "negatywne” elementy polityki narodowościowej w województwie poleskim. W praktyce w latach 30. wyeliminowano niemal w zupełności z tego obszaru instytucje polityczne, społeczne i gospodarcze mniejszości narodowych. Przejawy prób restytucji choćby nieformalnych wpływów organizacji mniejszościowych starano się do wybuchu wojny torpedować w zarodku104. Monopol zdobyły więc na Polesiu organizacje o polskim charakterze i prorządowym obliczu, które zresztą istotnie cieszyły się na wsi coraz większą popularnością ${ }^{105}$.

W latach 30. "tutejszość” W ujęciu władz nie była tylko obiektem polonizacyjnego ataku, ale teoretycznie dawała szansę na dopuszczenie do pożądanych na wsi procesów ekonomicznych. Obok Polaków jedynie zakwalifikowani do tej grupy zostali określeni jako możliwi beneficjenci reformy rolnej. Miano ich traktować równorzędnie z ubiegającymi się o ziemię Polakami106. Istnienie grupy „tutejszych” jako grupy „pokrewnej” Polakom warunkowało również koncepcje pożądanego zachowania się poborowych. W latach 30. udało się osiągnąć bardzo znaczący wzrost deklaracji polskości przez chłopskich prawosławnych mężczyzn przeznaczonych do odbycia służby wojskowej. W założeniu miało to

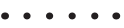

${ }^{99}$ Cуt zа: Борьба трудящихся Западной Белоруссии, за соцяльное и национальное освобождение и воссодинение с БССР, ред. А.Н. Мацинко, В.Н. Жугалов, Н.С. Орехво, t. 2, s. 436, 437.

100 PAOB, f. 1, o. 10, d. 2899, k. 184, Pismo wojewody poleskiego do ministra spraw wewnętrznych z 8 IX 1934 r.

101 P. Cichoracki, op. cit., s. 267-268.

102 PAOB, f. 1, o. 10, d. 2892, k. 3, Pismo wojewody poleskiego do wojewodów wileńskiego, nowogródzkiego i biatostockiego z 20 VI 1933 r.

103 Ibidem, d. 2890, k. 1. Pismo wojewody poleskiego do arcybiskupa polesko-pińskiego z $6 \mathrm{~V} 1933 \mathrm{r}$.

104 AAN, Úrząd Wojewódzki Poleski, sygn. 30, k. 31, Sprawozdanie sytuacyjne nr 4 za kwiecień z 9 V 1938 r.

105 А.М. Вабішчевіч, Нацыянальна-культурнае жыццё Заходняй Беларусі (1921-1939 г2.), Брест 2008 s. 153-154; Kresy w oczach oficerów KOP, red. J. Widacki, Katowice 2005, s. 195.

106 Борьба трудящихся..., t. 2, s. 436, 437. 
na celu ułatwienie przechodzenia w orbitę wpływów kultury polskiej przyszłego żołnierza służby zasadniczej, który dzięki zaliczeniu do grupy polskiej będzie lepiej traktowany w koszarach. Odbije się to także na jego postawie po powrocie do cywila107.

Konkludując, można uznać, że problem „tutejszości” znacznej części ludności Polesia wywoływał zainteresowanie, a nawet emocje w różnych sferach życia polskiego okresu międzywojennego. Z zasady był dostrzegany przez tych, którzy zajmowali się problematyką mniejszości narodowych czy to na niwie nauki, publicystyki, czy też administracji. Wnioski, jakie jednak wyciągano z uznania istnienia na Polesiu znaczącej grupy, która nie wykształciła ostatecznie poczucia tożsamości narodowej rozumianej stereotypowo jako identyfikacja z uznanymi wówczas narodami, był odmienne. Najbardziej wyraziście skalę rozbieżności oddają dzieje ujmowania zagadnienia w obrębie miejscowych władz polskich. Ich stanowisko miało też ostatecznie jedyny wpływ na codzienne funkcjonowanie mieszkańców. Zwraca uwagę, że miejscowa administracja, mimo znajomości wniosków z badań etnograficznych, które ogłaszane były systematycznie w dekadzie lat 30., a zwłaszcza w jej drugiej połowie, w praktyce ignorowała je. Tym samym można uznać, że w perspektywie, jaką stworzył 1939 r. przełożenie wysiłku specjalistów zajmujących się zagadnieniami poleskimi na praktykę polityczną okazało się niezauważalne. Pod koniec lat 30. można nawet mówić o symptomach procesu odwrotnego, przełożenia kształtu polityki narodowościowej na kierunek badań i wnioski wysnuwane przez specjalistów od spraw narodowościowych.

SO-CALLED 'TUTEJSI' IN POLESIA AS A POLITICAL ISSUE IN POLAND, 1921-1939

\section{Summary}

This article is an attempt to present the problem of repercussions of the assumption made in the Second Polish Republic that in Polesia there was a compact several hundred thousand group of people that do not have a modern national consciousness. In the interwar period this group was commonly referred to as 'tutejsi.' The issue is examined from three perspectives. The first is to reconstruct the position taken in this case by the Polish science, especially the authors gathered around the Institute for Nationalities Affairs (Instytut Badań Spraw Narodowościowych). The second part of the article presents opinions functioning about so-called 'tutejsi' in the Polish public opinion. The difference between points of view arising in the 1920s and '30s is exposed here. The third part focuses on the actions taken by the Polish authorities. In the first half of the '20s an assumption was formulated that in Polesia this group was dominant, therefore actions must be taken for its Polonization. After the military coup in 1926, the existence of 'tutejsi' was to a large extent disputed. The authorities stated that Polesia was populated mainly by Belarusians and Ukrainians. The reversal of this policy dates back to the early 1930s. The theory of the existence of 'tutejsi' - and at the same time their domination in Polesia - returned. It was believed they should be not only subject to Polonization, but also that they are particularly susceptible to it.

Keywords: so-called 'tutejsi' in Polesia, Polonization, Belarusians and Ukrainians, Institute for Nationalities Affairs in Warsaw

Translated by Michat Broda

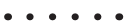

107 P. Cichoracki, op. cit., s. 278. 